\title{
PENERAPAN PSAK 109 PADA BAZNAS KOTA MAGELANG DAN FAKTOR- FAKTOR YANG MEMENGARUHINYA
}

\author{
Aulia Nur Latifah ${ }^{1)}$; Moh. Luthfi Mahrus ${ }^{2}$ \\ 1) aulialatiff@gmail.com, Program D3 Akuntansi Politeknik Keuangan Negara STAN \\ 2)*mluthfimahrus@pknstan.ac.id, Program D3 Akuntansi Politeknik Keuangan Negara STAN \\ *email korespondensi
}

\begin{abstract}
This study aims to analyze the implementation of PSAK 109 and the factors that influence it at BAZNAS Magelang City. This research was conducted in Magelang in February-April 2021. This research is a qualitative research with interview method to obtain primary data and literature study method to obtain secondary data. The results of this study indicate that BAZNAS Magelang City is still doing traditional zakat and infaq/alms accounting records and has not yet fully implemented PSAK 109, particularly related to the measurement, presentation, reporting, and disclosure of ZIS funds. As for the factors that influence the implementation of PSAK 109 at BAZNAS Magelang City, there are four factors that can be identified, namely differences in perceptions of the urgency of PSAK 109, limitations of information technology systems, limited human resources, and limited support from local governments. This study indicates that local governments need to provide adequate support for the implementation of PSAK 109, both policy support and financial support, which can accommodate the needs of information technology systems and human resource competencies. In addition, this study indicates that the central BAZNAS and the Indonesian Institute of Accountants (IAI) need to increase socialization and assistance to regional BAZNAS regarding the application of PSAK 109.
\end{abstract}

Keywords: Zakat Accounting, Baznas, Financial Accounting Standards

\begin{abstract}
Abstrak
Penelitian ini bertujuan untuk menganalisis penerapan PSAK 109 dan faktor-faktor yang memengaruhinya pada BAZNAS Kota Magelang. Penelitian ini dilakukan di Magelang pada bulan Februari-April 2021. Penelitian ini merupakan penelitian kualitatif dengan metode wawancara untuk memperoleh data primer dan metode studi pustaka untuk memperoleh data sekunder. Hasil penelitian ini menunjukkan bahwa BAZNAS Kota Magelang masih melakukan pencatatan akuntansi zakat dan infak/sedekah secara tradisional dan belum sepenuhnya menerapkan PSAK 109, khususnya terkait pengukuran, penyajian, pelaporan, dan pengungkapan dana ZIS. Adapun terkait faktor-faktor yang memengaruhi penerapan PSAK 109 pada BAZNAS Kota Magelang, terdapat empat faktor yang dapat diidentifikasi, yaitu perbedaan persepsi terhadap urgensi PSAK 109, keterbatasan sistem teknologi informasi, keterbatasan sumber daya manusia, dan keterbatasan dukungan dari pemerintah daerah. Penelitian ini mengindikasikan bahwa pemerintah daerah perlu memberikan dukungan secara memadai terhadap penerapan PSAK 109, baik dukungan kebijakan maupun dukungan dana, yang dapat mengakomodasi kebutuhan sistem teknologi informasi dan kompetensi sumber daya manusia. Selain itu, penelitian ini mengindikasikan bahwa BAZNAS pusat dan Ikatan Akuntan Indonesia (IAI) perlu meningkatkan sosialisasi dan asistensi kepada BAZNAS daerah terkait penerapan PSAK 109.
\end{abstract}

Kata Kunci : Akuntansi Zakat, Baznas, Standar Akuntansi Keuangan

\section{PENDAHULUAN}

Menurut Undang-Undang Nomor 23 Tahun 2011 tentang Pengelolaan Zakat, zakat adalah bagian tertentu dari harta yang wajib dikeluarkan oleh seorang muslim atau suatu badan usaha untuk diberikan kepada golongan yang berhak menerimanya sesuai ketentuan syariat Islam. Zakat merupakan salah satu dari lima rukun Islam yang wajib dilaksanakan oleh kaum muslimin dengan tujuan untuk membersihkan hati dan harta individu setiap muslim terhadap hak orang lain. Zakat dalam sejarah terbukti dapat mengentaskan kemiskinan sebagaimana yang terjadi pada zaman kepemimpinan Umar bin Khattab, khalifah kedua penerus perjuangan Nabi Muhammad SAW. Pada awal kepemimpinannya, Umar melakukan kunjungan ke negeri Yaman dan melihat banyak warga Yaman yang hidup dalam kesusahan, sehingga Umar membuat keputusan untuk mendirikan baitul mal, sebuah rumah amil zakat yang dimaksudkan 


\section{JURNALKU}

Volume 1 No. 4, Desember 2021

untuk mengelola zakat dari muzaki untuk kemudian disalurkan kepada para mustahik dengan sistem yang lebih terstruktur (Dompet Dhuafa, 2019).

Indonesia sebagai negara dengan populasi muslim terbesar di dunia tentu tidak dapat mengabaikan begitu saja potensi zakat yang ada, mengingat urgensi zakat berkaitan erat dengan pengentasan kemiskinan dan pemenuhan kebutuhan sosial lain, seperti pendidikan dan kesehatan yang bermanfaat bagi kemaslahatan umat. Bahkan, sejak penyebaran virus COVID19 ditetapkan Badan Kesehatan Dunia (WHO) sebagai pandemi pada 11 Maret 2020, Badan Amil Zakat Nasional (BAZNAS) telah memberikan respons cepat dengan membuat dua program yang berfokus pada penyaluran dana zakat dan infak/sedekah khusus terkait dana darurat kesehatan dan sosial ekonomi serta pengamanan program yang telah berjalan. Hingga 25 Mei 2020 BAZNAS Pusat tercatat telah menyalurkan dana sebesar Rp28,32 miliar untuk program tersebut (BAZNAS, 2020). Hal tersebut tentu menjadi contoh nyata bagaimana keuangan sosial Islam di masa kini dapat benar-benar memberi dampak yang nyata ketika diatur dengan sistem yang baik.

Riset yang dilakukan oleh The Islamic Research and Training Institute, Islamic Development Bank (IRTI-IDB) menyatakan bahwa potensi zakat nasional mencapai angka 217 triliun rupiah dalam setahun. Sebuah angka yang potensial ketika dana tersebut dapat seluruhnya terkumpul dan digunakan untuk kemaslahatan umat. Namun, dalam kenyataannya baru sekitar sembilan triliun rupiah atau hanya sekitar 4,1\% dari jumlah dana tersebut yang terealisasi dan tercatat masuk ke Badan Amil Zakat Nasional (DDTCNews, 2020).

Potensi zakat yang cukup besar sebenarnya telah disadari oleh pemerintah sejak lama, hingga pada tahun 2001 dibentuklah Badan Amil Zakat Nasional (BAZNAS) sebagai implementasi atas Undang-Undang Nomor 38 Tahun 1999 tentang Pengelolaan Zakat. Terbitnya Undang-Undang Nomor 23 Tahun 2011 yang menggantikan UU Nomor 38 Tahun 1999 semakin menguatkan peran BAZNAS sebagai lembaga resmi pemerintah yang berwenang mengelola zakat secara nasional. Saat ini BAZNAS memiliki jaringan atau perwakilan di 34 provinsi dan 463 kabupaten/kota (baznas.go.id).

Dalam rangka menciptakan sistem pencatatan zakat yang terintegrasi dan sesuai tata kelola yang baik (good corporate governance), Dewan Standar Akuntansi Keuangan Ikatan Akuntan Indonesia (DSAK IAI) mengesahkan Pernyataan Standar Akuntansi Keuangan (PSAK) 109 tentang Akuntansi Zakat dan Infak/Sedekah (ZIS) pada tanggal 6 April 2010 sebagai pedoman dalam pembukuan dan pelaporan keuangan bagi lembaga amil dan berlaku efektif per tanggal 1 Januari 2012. Penerbitan PSAK 109 dilakukan karena sebelumnya belum ada standar yang mengatur secara spesifik terkait akuntansi zakat dan infak/sedekah. Sebelumnya, organisasi pengelola zakat menggunakan PSAK 45 tentang Pelaporan Keuangan Organisasi Nirlaba yang di dalamnya tidak terdapat aturan yang jelas mengenai pengelolaan dana zakat dan infak/sedekah. Dengan adanya PSAK 109, seluruh lembaga amil zakat, termasuk BAZNAS, diharapkan dapat menerapkannya dalam pencatatan transaksi sehari-hari dan penyusunan laporan keuangan. Namun demikian, beberapa hasil penelitian menunjukkan bahwa meskipun sudah 10 tahun berlalu sejak PSAK 109 ditetapkan pada tanggal 6 April 2010, hingga kini masih banyak BAZNAS di provinsi dan kabupaten/kota yang belum menerapkan PSAK 109 secara memadai, bahkan di antaranya masih menggunakan sistem pembukuan secara manual dan masih sangat sederhana. Padahal, BAZNAS telah membangun dan mengembangkan sebuah Sistem Manajemen Informasi BAZNAS (SiMBA) yang memudahkan manajemen BAZNAS, baik pusat maupun daerah, dalam mencatat transaksi dan menyusun laporan keuangan sesuai PSAK 109.

Berdasarkan hasil penelitian pada beberapa BAZNAS Provinsi, diketahui bahwa BAZNAS Provinsi Sulawesi Utara (Shahnaz, 2015), BAZNAS Provinsi Sumatera Utara (Ritonga, 2017), dan BAZNAS Provinsi Sulawesi Selatan (Majid et al., 2020) belum 


\section{JURNALKU}

Volume 1 No. 4, Desember 2021

sepenuhnya menerapkan PSAK 109 secara memadai. Sementara itu, hasil penelitian mengenai penerapan PSAK 109 pada beberapa BAZNAS Kabupaten/Kota menunjukkan bahwa mayoritas BAZNAS Kabupaten/Kota belum sepenuhnya menerapkan PSAK 109. Di tingkat BAZNAS Kabupaten, di antara BAZNAS yang belum sepenuhnya menerapkan PSAK 109 adalah BAZNAS Kabupaten Solok (Rizal et al., 2017), BAZNAS Kabupaten Majene (Hadijah, 2019), BAZNAS Kabupaten Tulungagung (Susilowati \& Khofifa, 2020), BAZNAS Kabupaten Sukabumi (Kartini, 2020), BAZNAS Kabupaten Magelang (Yanuar et al., 2020), BAZNAS Kabupaten Jember (Wijayanti et al., 2020), BAZNAS Kabupaten Sragen (Sari et al., 2020), BAZNAS Kabupaten Tasikmalaya (Rokib et al., 2021), dan BAZNAS Kabupaten Nganjuk (Putri \& Awalina, 2021). Adapun di tingkat BAZNAS Kota, BAZNAS yang belum sepenuhnya menerapkan PSAK 109 antara lain BAZNAS Kota Manado (Arief et al., 2017), BAZNAS Kota Makassar (Bulutoding \& Anggeriani, 2018), BAZNAS Kota Gorontalo (Bakri, 2019), BAZNAS Kota Tual (Ohoirenan dan Fithria, 2020), BAZNAS Kota Pangkalpinang (Ikbal et al., 2021), BAZNAS Kota Salatiga (Nisa et al., 2021), BAZNAS Kota Baubau (Ridjali \& Malik, 2021), dan BAZNAS Kota Padang (Sartika et al., 2021).

Fenomena di atas merupakan salah satu hal yang menarik untuk diteliti lebih mendalam sesuai dengan keadaan terkini, khususnya terkait dengan faktor penyebab BAZNAS daerah belum sepenuhnya mengimplementasikan PSAK 109. Hal ini mengingat penelitian-penelitian sebelumnya sebagian besar berfokus pada penerapan PSAK 109 pada BAZNAS daerah, mulai dari pengakuan, pengukuran, penyajian, dan pengungkapan. Sangat sedikit sekali penelitian yang berusaha menggali secara komprehensif faktor-faktor penyebab atau alasan belum diterapkannya PSAK 109 secara memadai oleh manajemen BAZNAS daerah. Di antara penelitian yang menyinggung kendala atau penyebab belum diterapkannya PSAK 109 secara memadai oleh manajemen BAZNAS daerah adalah penelitian Bakri (2019), Susilowati \& Khofifa (2020), Kartini (2020), dan Sartika et al. (2021) dan kesemuanya menyatakan bahwa sumber daya manusia merupakan faktor penyebab utama BAZNAS daerah sepenuhnya mengimplementasikan PSAK 109 secara memadai. Selain penelitian-penelitian tersebut, terdapat penelitian Rahmawati dan P. (2013) pada BAZNAS dan LAZ Lembaga Manajemen Infaq di Sidoarjo yang menyatakan bahwa di antara kendala dalam penerapan PSAK 109 adalah karena PSAK tersebut sulit dipahami dan diterapkan dalam proses penyusunan laporan keuangan.

Berbeda dengan penelitian-penelitian sebelumnya, penelitian ini dilakukan dengan tujuan untuk menganalisis penerapan PSAK 109 pada BAZNAS daerah secara komprehensif beserta faktor-faktor yang memengaruhinya, khususnya faktor penyebab belum diterapkannya PSAK 109 secara optimal. Subjek penelitian ini adalah BAZNAS Kota Magelang yang pada saat penelitian dilakukan (awal 2021), masih belum sepenuhnya menerapkan PSAK 109 dan masih melakukan pencatatan pembukuan secara tradisional, padahal BAZNAS Kota Magelang telah resmi berdiri pada 23 Agustus 2016 dan mulai melakukan kegiatan pengumpulan dan penyaluran zakat sejak bulan November 2016. Selanjutnya, penelitian ini diharapkan dapat memberikan kontribusi pada perkembangan penelitian di bidang akuntansi zakat, sekaligus dapat memberikan masukan kepada pemerintah dan pihak-pihak terkait, seperti IAI, sehingga penerapan PSAK 109 pada BAZNAS daerah dan lembaga amil zakat yang lain dapat dilakukan secara optimal guna mewujudkan tata pengelolaan zakat secara transparan dan akuntabel.

\section{KAJIAN PUSTAKA}

Dari segi bahasa, zakat berasal dari kata zaka yang berarti suci, bersih, baik, bertumbuh, dan berkembang (Mas'amah, 2019). Dari segi istilah, menurut Undang-Undang Nomor 23 Tahun 2011 tentang Pengelolaan Zakat, zakat merupakan harta yang wajib dikeluarkan oleh seorang muslim atau suatu entitas usaha untuk kemudian diberikan kepada pihak yang berhak 


\section{JURNALKU}

Volume 1 No. 4, Desember 2021

menerimanya sesuai dengan ketentuan syariat Islam. Sejalan dengan definisi tersebut, dalam PSAK 109 paragraf 5 dijelaskan bahwa zakat adalah harta yang wajib dikeluarkan oleh individu muslim yang secara syariat wajib membayar atau menunaikan zakat (muzaki) sesuai dengan ketentuan syariat untuk diberikan kepada yang berhak menerimanya (mustahik). Dari beberapa pengertian zakat di atas, dapat disimpulkan bahwa zakat adalah sejumlah tertentu dari harta yang bertumbuh dan berkembang yang wajib dikeluarkan oleh orang yang telah memenuhi syarat untuk diberikan kepada yang berhak menerima dengan harapan harta tersebut berkah, dapat membersihkan jiwa, dan juga menuntun kepada kebaikan.

Zakat memiliki kedudukan yang penting dalam ajaran agama Islam. Sebagai rukun Islam ketiga, kedudukan zakat dalam Islam adalah sebagai salah satu pondasi wajib dan dasar dari kehidupan dalam beragama bagi orang-orang yang beriman. Dengan kata lain, salah satu kriteria seseorang dapat dikatakan sebagai muslim yang baik adalah ketika orang tersebut telah menunaikan zakat sesuai dengan ketentuan yang telah ditetapkan dalam syariat Islam.

Dalam zakat, telah ditentukan syarat dan ketetapan tertentu seperti nisab (jumlah harta benda minimum yang dikenakan zakat), haul (jangka waktu kepemilikan harta), tarif zakat (qadar), dan juga jenis peruntukan zakat (fitrah/mal). Dalam Al-Quran, diterangkan bahwa terdapat delapan golongan yang berhak menerima zakat seperti yang diterangkan dalam surat At-Taubah ayat 60. Golongan tersebut meliputi fakir, miskin, amil, mualaf, riqab, gharim, fisabilillah, dan ibnu sabil. Tabel II.1 berikut menjelaskan pengertian dari masing-masing istilah yang digunakan untuk menyebut golongan orang yang berhak menerima zakat.

\section{Tabel 1. Golongan Orang yang Berhak Menerima Zakat}

\begin{tabular}{|c|l|l|}
\hline No & \multicolumn{1}{|c|}{ Golongan } & \multicolumn{1}{c|}{ Pengertian } \\
\hline 1 & Fakir & $\begin{array}{l}\text { Orang yang tidak memiliki pekerjaan dan penghasilan karena ada uzur syariat } \\
\text { sehingga tidak dapat mencukupi kebutuhan pokok, baik untuk dirinya } \\
\text { maupun keluarganya. }\end{array}$ \\
\hline 2 & Miskin & $\begin{array}{l}\text { Orang yang memiliki penghasilan tetapi tidak cukup untuk memenuhi } \\
\text { kebutuhan pokok dirinnya dan keluarganya. }\end{array}$ \\
\hline 3 & Amil & $\begin{array}{l}\text { Orang yang telah ditugaskan untuk mengumpulkan, mengelola, serta } \\
\text { menyalurkan zakat dan infak/sedekah. }\end{array}$ \\
\hline 4 & Mualaf & $\begin{array}{l}\text { Orang yang baru masuk Islam dan dianggap masih lemah imannya sehingga } \\
\text { harus diperkuat. }\end{array}$ \\
\hline 5 & Riqab & $\begin{array}{l}\text { Memerdekakan budak atau hamba sahaya dan menghilangkan semua bentuk } \\
\text { perbudakan. Budak yang dimaksud adalah seorang muslim yang dibebaskan } \\
\text { dengan harta zakat. }\end{array}$ \\
\hline 7 & Fisabilillah & $\begin{array}{l}\text { Orang yang terlilit utang untuk kepentingan yang bukan maksiat dan tidak } \\
\text { mampu untuk melunasinnya. }\end{array}$ \\
\hline 8 & $\begin{array}{l}\text { Orang yang berjuang di jalan Allah SWT demi mengharapkan rida. Di masa } \\
\text { kini, jihad fisabilillah tidak selalu berarti perang, melainkan dapat dilakukan } \\
\text { dengan belajat giat demi ridha Allah, penyiaran dakwah Islam, proyek } \\
\text { pembangunan masjid dan kegiatan lain di jalan Allah. }\end{array}$ \\
\hline Ibnu sabil & $\begin{array}{l}\text { Orang yang sedang dalam perjalanan dalam hal kebaikan dan kehabisan bekal } \\
\text { dalam perjalanannya tesebut. }\end{array}$ \\
\hline
\end{tabular}

Sumber: Hadziq ( 2013)

Mengenai definisi infak, dari segi bahasa, infak berasal dari kata bahasa Arab anfaqayunfiqu-infaq yang berarti membiayai atau membelanjakan (Hadziq, 2013). Sementara itu, dari segi istilah, infak berarti mengeluarkan atau membelanjakan sebagian dari harta atau penghasilan sebagai bentuk rasa syukur atas anugerah dan nikmat yang telah diberikan oleh Allah SWT (Rahman, 2015). Dalam praktiknya, infak relatif lebih mudah untuk dilakukan karena tidak memiliki syarat-syarat khusus seperti dalam zakat. Hal ini membuat semua umat 


\section{JURNALKU}

Volume 1 No. 4, Desember 2021

muslim dengan segala kondisi baik lapang maupun sempit, kaya maupun miskin, muda maupun tua dan dengan latar belakang apapun dapat menunaikan infak.

Adapun sedekah berasal dari kata dalam Bahasa Arab, yaitu shadaqa yang artinya benar (Hadziq, 2013). Benar di sini berarti bahwa orang yang melakukan sedekah adalah orang yang benar dalam beriman dan bersedekah dengan niat semata-mata untuk mendapatkan balasan pahala dari Allah SWT dan bukan menunaikan sedekah karena mengharap pengakuan duniawi (Hadziq, 2013). Hal ini sejalan dengan pernyataan Rahman (2015) yang menjelaskan bahwa sedekah merupakan segala pemberian atau kegiatan yang bertujuan hanya untuk mengharap pahala dari Allah SWT.

Undang-Undang Nomor 23 Tahun 2011 tentang Pengelolaan Zakat membedakan definisi infak dan sedekah, yaitu infak terbatas pada harta, sedangkan sedekah dapat berupa harta dan nonharta. Hal ini menunjukkan bahwa sedekah cenderung memiliki batasan dan arti yang lebih luas daripada infak, yaitu sedekah tidak hanya mencakup pemberian sesuatu dalam bentuk uang dan barang, tetapi dapat berupa perbuatan kebajikan, baik yang bermanfaat bagi diri sendiri maupun untuk orang lain (Rahman, 2015). Adapun dalam rangka kepentingan pencatatan akuntansi, pengertian sedekah dianggap sama dengan infak. Menurut PSAK 109 paragraf 5, infak/sedekah didefinisikan sebagai harta yang diberikan secara sukarela oleh pemiliknya, baik yang peruntukannya ditentukan/dibatasi atau tidak.

Di Indonesia pengelolaan zakat dilakukan oleh Badan Amil Zakat Nasional (BAZNAS) dan Lembaga Amil Zakat (LAZ) yang dibentuk oleh masyarakat dan disahkan oleh pemerintah. Menurut Undang-Undang Nomor 23 Tahun 2011 tentang Pengelolaan Zakat, BAZNAS adalah lembaga pemerintah yang bersifat mandiri dan bertanggungjawab kepada presiden melalui menteri agama dan memiliki wewenang untuk melakukan pengelolaan zakat secara nasional. Hal tersebut sesuai dengan bentuk BAZNAS yang merupakan lembaga pemerintah nonstruktural, yaitu lembaga yang dibentuk berdasarkan peraturan perundang-undangan tertentu guna menunjang pelaksanaan fungsi negara dan pemerintah. BAZNAS terbentuk berdasarkan Keputusan Presiden RI Nomor 8 Tahun 2001 pada tanggal 17 Januari 2001.

Secara lebih ringkas, dapat dinyatakan bahwa BAZNAS merupakan lembaga mandiri pembantu pemerintah dalam hal ini Kementerian Agama, yang memiliki tanggung jawab untuk mengawal proses pengelolaan zakat dengan asas syariat Islam, amanah, kemanfaatan, keadilan kepastian hukum, serta terintegrasi dan akuntabilitas. Dalam melaksanakan tugasnya, BAZNAS menyelenggarakan empat fungsi, yaitu perencanaan, pelaksanaan, dan pengendalian terkait pengumpulan, pendistribusian, dan pendayagunaan Zakat, Infak, dan Sedekah (ZIS), serta pelaporan dan pertanggungjawaban pelaksanaan pengelolaan ZIS. Selain itu, untuk mendukung pelaksanaan keempat fungsi tersebut secara efektif dan efisien, BAZNAS memiliki tiga wewenang tambahan, yaitu 1) menghimpun, mendistribusikan, dan mendayagunakan zakat, 2) memberikan rekomendasi dalam pembentukan BAZNAS Provinsi, BAZNAS kabupaten/kota, dan LAZ, dan 3) meminta laporan pelaksanaan pengelolaan zakat, infak, sedekah, dan dana sosial keagamaan lainnya kepada BAZNAS Provinsi dan LAZ.

Dalam mengelola ZIS, khususnya terkait pencatatan dan pelaporan ZIS, BAZNAS dan LAZ harus berpedoman pada ketentuan standar akuntansi keuangan mengenai akuntansi ZIS. Akuntansi ZIS secara umum dapat diartikan sebagai proses pengakuan, pengukuran, penyajian, dan pengungkapan atas transaksi zakat dan infak/sedekah yang dilakukan sesuai dengan syariat Islam guna dapat menyajikan informasi terkait pengelolaan dana zakat dan infak/sedekah yang dilakukan oleh amil kepada pihak-pihak yang memiliki kepentingan dengan informasi tersebut (Rahmawati \& P, 2013). Selanjutnya, terdapat tiga hal pokok yang menjadi fokus akuntansi ZIS, yaitu yaitu penyediaan informasi akuntansi untuk pengambilan keputusan, pengendalian manajemen, dan akuntabilitas (Ritonga, 2017). 


\section{JURNALKU}

Volume 1 No. 4, Desember 2021

Akuntansi zakat dan infak/sedekah di Indonesia secara khusus telah diatur dalam PSAK 109 yang diterbitkan pada 6 April 2010 dan berlaku efektif per 1 Januari 2012. Dalam PSAK 109 disebutkan bahwa sebuah entitas pengelola zakat dan infak/sedekah atau amil zakat harus melakukan pengakuan, pengukuran, penyajian, serta pengungkapan sesuai dengan ketentuan yang telah ditetapkan oleh IAI berdasarkan PSAK 109. Adapun komponen laporan keuangan yang harus dimiliki oleh amil juga telah ditentukan, yaitu neraca (laporan posisi keuangan), laporan perubahan dana, laporan perubahan aset kelolaan, laporan arus kas, dan catatan atas laporan keuangan.

\section{METODE}

Penelitian ini menggunakan metode kualitatif karena penelitian kualitatif memungkinkan peneliti memperoleh pemahaman yang lebih baik melalui kedekatan dengan objek yang diteliti (Aspers \& Corte, 2019). Dalam penelitian ini, pihak yang menjadi subjek penelitian adalah BAZNAS Kota Magelang yang beralamat di yang beralamat di Jalan Pahlawan No. 94 Potrobangsan.

Penelitian ini dilakukan di Magelang pada bulan Ferbuari-April 2021. Data yang digunakan dalam penelitian ini meliputi data sekunder dan primer. Data sekunder berupa literatur yang membahas permasalahan terkait pengelolaan zakat dan penerapan PSAK 109 pada BAZNAS daerah, serta data laporan keuangan yang disusun oleh BAZNAS Kota Magelang. Adapun data primer berupa keterangan dari pegawai dan pengurus BAZNAS Kota Magelang serta keterangan dari narasumber terkait.

Data sekunder diperoleh dengan cara mengumpulkan, membaca, dan menelaah lebih dalam terkait informasi yang berkaitan dengan masalah yang diteliti, yaitu penerapan PSAK 109 pada BAZNAS daerah. Sumber kepustakaan yang digunakan untuk mendapatkan data sekunder adalah jurnal ilmiah, peraturan perundang-undangan, buku, laman, serta literatur lain yang memiliki kredibilitas dan pertanggungjawaban terkait informasi yang disediakan. Metode ini dipilih guna mendapatkan informasi yang berkaitan dengan permasalahan yang diangkat secara lebih mendalam sehingga dapat melakukan analisis permasalahan dengan lebih baik.

Adapun data primer diperoleh dengan metode wawancara. Dalam penelitian ini, dilakukan wawancara terhadap tiga pihak berbeda yang memiliki pemahaman atas informasi akuntansi yang dihasilkan oleh BAZNAS. Wawancara ini dilakukan untuk memperoleh data primer berupa fakta dan pendapat dan juga data analisis dari berkaitan dengan permasalahan yang diteliti. Pihak pertama dan pihak kedua yang menjadi narasumber adalah Kepala Unit Pelaksana dan Amil Bidang Keuangan (Staf Akuntansi) BAZNAS Kota Magelang. Wawancara kepada kedua pihak ini dilakukan untuk mendapatkan gambaran riil dari pelaku kegiatan dan juga latar belakang pengambilan keputusan berdasarkan informasi akuntansi yang dihasilkan. Sementara itu, pihak ketiga yang menjadi narasumber adalah seorang ahli dalam bidang akuntansi syariah yang juga berprofesi sebagai auditor di sebuah kantor akuntan publik. Hal ini dilakukan guna mendapatkan pendapat ahli terkait situasi dan kondisi penerapan akuntansi yang diterapkan di BAZNAS Kota Magelang.

Data yang telah dikumpulkan selanjutnya dianalisis menggunakan metode interpretatif untuk mendapatkan pemahaman yang mendalam mengenai fakta penerapan PSAK 109 pada BAZNAS Kota Magelang beserta faktor-faktor yang memengaruhinya. Hasil analisis kemudian dituangkan dalam pembahasan secara komprehensif.

\section{HASIL DAN PEMBAHASAN \\ Pengakuan dan Pengukuran Dana ZIS}

Dalam PSAK 109 paragraf 10 dan 11 dinyatakan bahwa penerimaan zakat diakui pada saat kas atau aset nonkas diterima. Penerimaan tersebut diakui sebagai penambah dana zakat 


\section{JURNALKU}

Volume 1 No. 4, Desember 2021

sebesar jumlah yang diterima apabila dalam bentuk kas, tetapi apabila dalam bentuk nonkas diakui sebesar nilai wajar aset yang diterima. Penentuan nilai wajar aset nonkas menggunakan harga pasar atau metode penentuan nilai wajar lainnya sesuai dengan SAK yang relevan. Tabel 2 di bawah ini menyajikan perbandingan mekanisme pengakuan dan pengukuran yang dilakukan oleh BAZNAS Kota Magelang dengan ketentuan yang terdapat dalam PSAK 109.

Tabel 1. Pengakuan dan Pengukuran Dana ZIS Menurut BAZNAS Kota Magelang dan PSAK 109

\begin{tabular}{|c|c|}
\hline BAZNAS Kota Magelang & PSAK 109 \\
\hline $\begin{array}{l}\text { 1) BAZNAS Kota Magelang mengakui dana ZIS } \\
\text { ketika uang dari muzaki telah diterima. }\end{array}$ & $\begin{array}{l}\text { 1) Penerimaan zakat diakui pada saat kas atau aset } \\
\text { nonkas diterima. }\end{array}$ \\
\hline $\begin{array}{l}\text { 2) Dana ZIS yang diterima diakui sebagai } \\
\text { penambah dana ZIS sesuai dengan ikrar } \\
\text { mustahik sebesar jumlah yang diterima. } \\
\text { 3) Dana ZIS yang disalurkan kepada mustahik } \\
\text { diakui sebagai pengurangan dana ZIS. }\end{array}$ & $\begin{array}{l}\text { 2) Infak/sedekah yang diterima diakui sebagai } \\
\text { penambah dana infak/sedekah terikat atau tidak } \\
\text { terikat sesuai dengan tujuan pemberian infaq/sedekah } \\
\text { sebesar jumlah yang diterima dan nilai wajar jika } \\
\text { dalam bentuk nonkas. }\end{array}$ \\
\hline $\begin{array}{l}\text { 4) Dana ZIS yang diterima diambil sebagian } \\
\text { sesuai ketentuan syariat sebagai dana amil, dan } \\
\text { dana ZIS nonamil diakui sebagai milik } \\
\text { penerima dana ZIS nonamil. }\end{array}$ & $\begin{array}{l}\text { 3) Penyaluran zakat kepada mustahik diakui sebagai } \\
\text { pengurangan dana zakat. } \\
\text { 4) Penyaluran infak/sedekah kepada mustahik diakui } \\
\text { sebagai pengurangan dana infak/sedekah. } \\
\text { 5) ZIS yang diterima diakui sebagai dana amil untuk } \\
\text { bagian amil, dan dana ZIS untuk bagian non amil atau } \\
\text { penerima infak/sedekah. }\end{array}$ \\
\hline
\end{tabular}

Sumber: Diolah Penulis

Berdasarkan Tabel 2 di atas, diperoleh informasi bahwa dana ZIS pada BAZNAS Kota Magelang diakui saat dana dari muzaki diterima oleh pihak BAZNAS (cash basis). Hal tersebut berlaku untuk semua jenis dana, baik dana yang diterima secara langsung maupun dana dari pihak ketiga. Dana yang diterima secara langsung adalah dana ZIS yang bersumber dari muzaki yang datang langsung menemui pengurus di kantor BAZNAS untuk menyerahkan dana ZIS mereka maupun dana yang diambil dari muzaki dengan sistem jemput donasi. Sementara itu, dana dari pihak ketiga adalah dana yang diterima dari pihak bank yang kemudian dibuktikan dengan rekening koran.

Dalam hal pengakuan aset kas, BAZNAS Kota Magelang telah menerapkan ketentuan PSAK 109, yaitu dengan mengakui dana ZIS yang diterima dari muzaki sebagai penambah dana ZIS. Hal tersebut sesuai dengan PSAK 109 paragraf 9 dan 10 yang menyatakan bahwa penerimaan zakat diakui pada saat kas atau aset lainnya diterima. Selain itu, zakat yang diterima dari muzaki harus diakui sebagai penambah dana zakat. Standar ini direkomendasikan karena ketika amil menerapkannya, maka saldo tercatat akan mencerminkan posisi saldo riil yang terkumpul di dalam rekening bank maupun kas amil, sehingga memudahkan proses alokasi dana ZIS. Namun, terdapat kelemahan dalam metode ini, yaitu timbulnya dana ZIS yang telah masuk dalam rekening bank, tetapi belum dapat diakui karena rekening koran belum terbit. Di sisi lain, BAZNAS Kota Magelang masih belum memiliki gambaran terkait pengakuan aset nonkas. Hal ini dikarenakan pihak BAZNAS sejak resmi beroperasi pada 2016 hingga kini belum pernah menerima zakat maupun infak/sedekah berupa aset nonkas, sehingga proses pengakuan aset nonkas belum pernah terjadi.

Terkait pengakuan dan sumber dana amil, selain menggunakan dana APBD Pemerintah Kota Magelang, BAZNAS Kota Magelang juga menggunakan hak amil dari zakat sebesar $12,5 \%$ dan hak dari infak/sedekah sebesar $20 \%$. Hak tersebut telah sesuai dengan ketentuan Peraturan BAZNAS No 1 Tahun 2016 pasal IV ayat 1 dan 2. Berdasarkan PSAK 109, hal tersebut juga telah memenuhi ketentuan sesuai dengan paragraf 12 dan 20 yang menyatakan dana ZIS yang diterima terbagi menjadi dua, yakni diakui sebagai dana amil untuk bagian amil dan dana nonamil sebagai dana untuk bagian penerima ZIS. 


\section{JURNALKU}

Volume 1 No. 4, Desember 2021

Terkait masalah pengukuran, penerimaan kas dana ZIS pada BAZNAS Kota Magelang diukur sebesar jumlah kas yang diterima, baik yang melalui mekanisme langsung maupun melalui transfer bank, dalam hal ini telah sesuai dengan standar yang ada. Untuk aset nonkas, selain disebabkan hingga saat ini BAZNAS Kota Magelang belum pernah menerima ZIS berupa aset nonkas, BAZNAS Kota Magelang juga belum memahami dan mengetahui tentang standar pengukuran aset nonkas. Adapun untuk pengukuran hak amil, sebagaimana yang telah dijelaskan sebelumnya, hak amil diukur sebesar $12,5 \%$ dari dana zakat dan $20 \%$ dari dana infak/sedekah serta ditambah dengan jumlah kas yang diterima BAZNAS dari APBD.

\section{Pelaporan dan Penyajian Dana ZIS}

PSAK 109 paragraf 38 menyebutkan bahwa dana zakat, dana infak/sedekah, dan dana amil disajikan oleh amil secara terpisah dalam laporan posisi keuangan. Dalam hal ini, amil harus membuat pos sendiri untuk dana zakat, dana infak/sedekah, dan dana amil dalam laporan keuangan. Terkait dengan hal itu, BAZNAS Kota Magelang belum sepenuhnya memenuhi standar PSAK 109. Hal tersebut ditunjukan dalam hal penyusunan laporan keuangan.

Laporan keuangan yang dihasilkan oleh BAZNAS Kota Magelang masih sangat sederhana dan belum menjelaskan secara rinci masing-masing pos dana secara terpisah. Selain itu, dari lima jenis laporan keuangan yang diwajibkan dalam standar PSAK 109, sejauh ini BAZNAS Kota Magelang hanya mampu menerbitkan tiga laporan keuangan, neraca, laporan perubahan dana, dan laporan arus kas. Pihak BAZNAS Kota Magelang belum dapat menyusun laporan perubahan aset kelolaan dan catatan atas laporan keuangan. Meskipun sudah dapat menerbitkan tiga dari lima laporan keuangan, akun-akun dalam laporan keuangan yang terbit masih menggunakan akun umum dan belum dirinci berdasarkan detail jenis alokasi dan transaksi. Padahal, menurut ketentuan PSAK 109, amil harus menyajikan komponen laporan keuangan secara lengkap. Selain itu, neraca atas dana zakat, infak/sedekah, dana amil, dan dana nonhalal juga masih belum disajikan secara terpisah sesuai dengan standar dalam PSAK 109. Selanjutnya, perbandingan mekanisme penyajian dan pelaporan antara BAZNAS Kota Magelang dengan PSAK 109 dapat dilihat pada Tabel 3 berikut.

Tabel 3 Penyajian dan Pelaporan Dana ZIS Menurut BAZNAS Kota Magelang dan PSAK 109

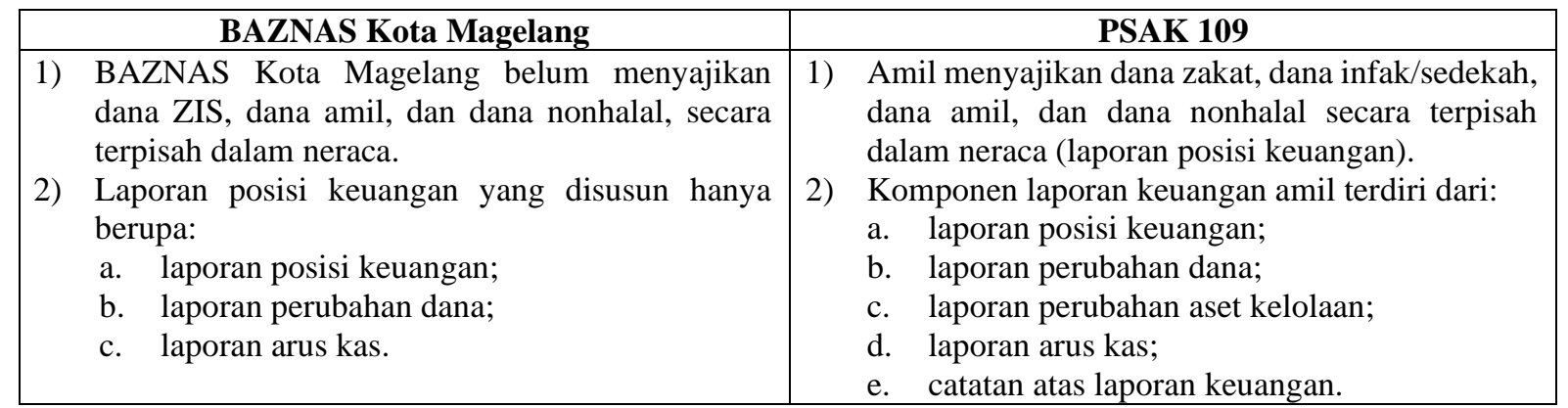

Sumber: Diolah penulis

\section{Pengungkapan Dana ZIS}

Berdasarkan PSAK 109 paragraf 35 dan 36 tentang pengungkapan akuntansi ZIS, dinyatakan bahwa amil zakat harus mengungkapkan hal-hal yang terkait dengan transaksi zakat, infak, maupun sedekah secara rinci. Dalam praktiknya, penyaluran dana ZIS BAZNAS Kota Magelang dilakukan berdasarkan alokasi pagu yang telah disusun di awal tahun dengan sasaran yang telah disurvei oleh pihak BAZNAS, baik secara langsung maupun melalui pengecekan dokumen tertentu yang berhubungan dengan penerimaan bantuan. Untuk kasus force majeure, seperti biaya rumah sakit, dana disalurkan dengan memeriksa terlebih dahulu keadaan yang sebenar-benarnya dengan mengonfirmasi pihak rumah sakit dan keterangan perangkat desa terkait keadaan terkini calon penerima bantuan. 
Selain pengungkapan informasi akuntansi sesuai dengan PSAK 109 paragraf 35 dan 36, terdapat pula hal-hal lain terkait pengungkapan yang didasarkan pada PSAK 109 paragraf 39 dan 40. Dalam hal ini, penulis telah melakukan analisis perbedaan pengungkapan berdasarkan wawancara dan juga laporan keuangan BAZNAS Kota Magelang Tahun 2020. Tabel 4 di bawah ini menyajikan perbandingan pengungkapan yang dilakukan oleh BAZNAS Kota Magelang dan ketentuan dalam PSAK 109.

Tabel 4. Perbandingan Pengungkapan Dana ZIS Menurut BAZNAS Kota Magelang dan PSAK 109

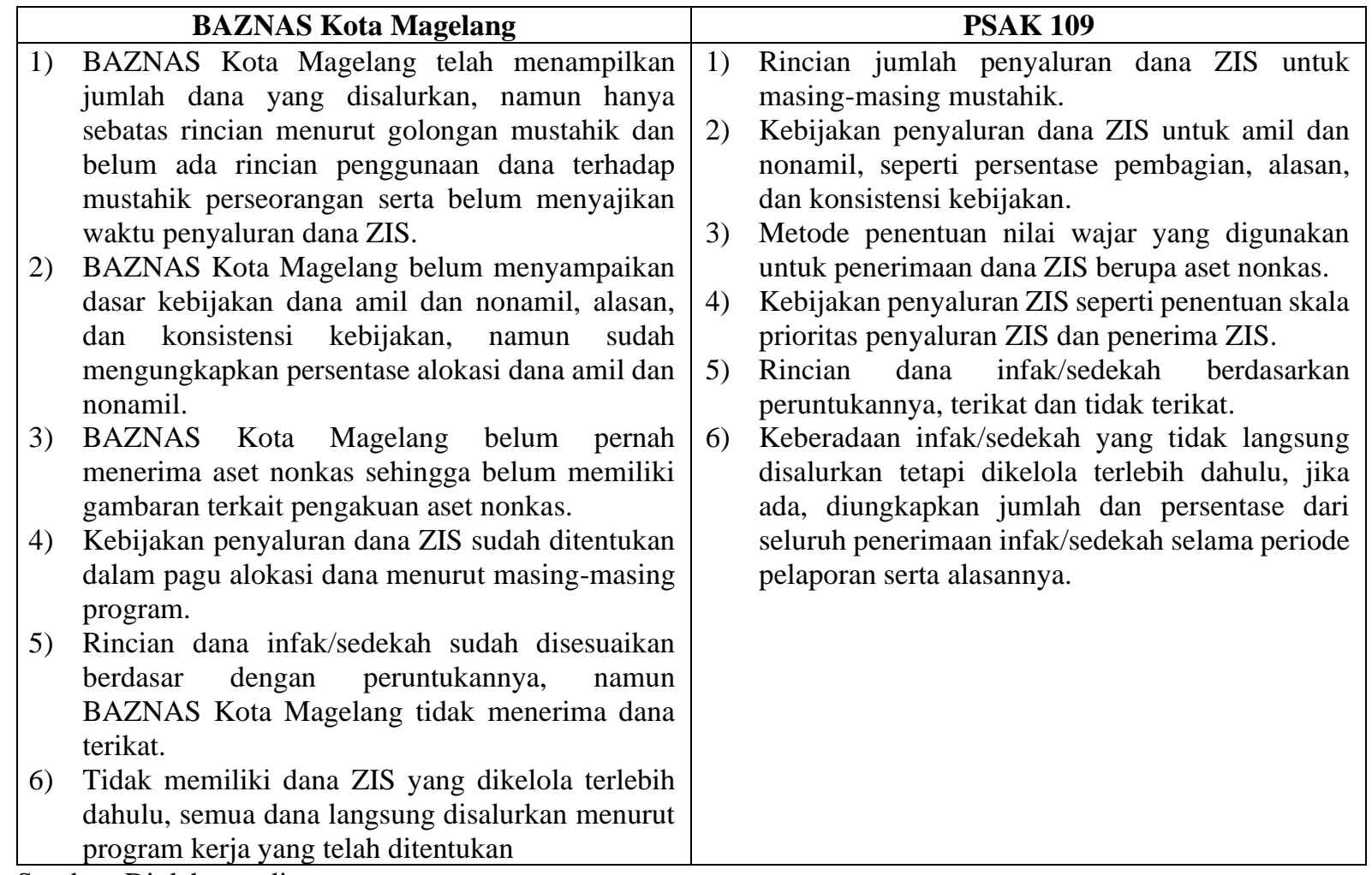

Sumber: Diolah penulis

Dari Tabel 4 di atas, diketahui bahwa terdapat empat dari enam kebijakan minimum terkait pengungkapan yang belum diterapkan oleh BAZNAS Kota Magelang. Empat kebijakan minimum tersebut meliputi belum adanya rincian jumlah penyaluran dana ZIS, landasan kebijakan persentase dana amil dan dana nonamil serta konsistensi kebijakannya, pemahaman tentang aset nonkas, dan kebijakan penyaluran dana ZIS. Adapun terkait pengungkapan terkait hak amil dan biaya operasional sebesar $20 \%$ dari infak/sedekah dan 12,5\% dari zakat, BAZNAS Kota Magelang telah melakukan pengungkapan penggunaan dana tersebut, tetapi tanpa rincian penggunaan yang jelas. Tanpa rincian di sini maksudnya adalah data yang disajikan hanya berupa data arus kas masuk dan keluar tanpa ada penamaan akun yang jelas menunjukkan penggunaan dana atas hak amil tersebut. Oleh karena itu, BAZNAS Kota Magelang belum memenuhi prinsip pengungkapan penuh (full disclosure).

\section{Informasi Akuntansi dan Sistem Pengambilan Keputusan}

Berdasarkan informasi yang termuat dalam pembahasan pengakuan akuntansi ZIS, telah disajikan informasi terkait ketentuan yang seharusnya tersaji dalam laporan keuangan maupun catatan atas laporan keuangan. Dari data yang ada, diketahui bahwa BAZNAS Kota Magelang belum sepenuhnya menerapkan standar yang berlaku. Belum diterapkannya standar akuntansi, baik sesuai keputusan IAI maupun imbauan Kementerian Agama terkait penggunaan PSAK 109 sebagai dasar pengelolaan keuangan BAZNAS, membuat penyajian beberapa informasi tidak sesuai dengan standar yang ada. Hal ini menyebabkan pengungkapan informasi akuntansi 


\section{JURNALKU}

Volume 1 No. 4, Desember 2021

di BAZNAS Kota Magelang menjadi tidak tersaji secara full disclosure, padahal pengungkapan merupakan standar dasar dalam akuntansi dan hal yang sangat penting dalam laporan keuangan.

Tujuan dari pengungkapan adalah memberikan informasi yang penting dan relevan kepada para pemakai laporan keuangan, sehingga dapat membantu pengguna laporan keuangan dalam membuat keputusan dengan cara yang terbaik (Kieso et al., 2018). Dalam literatur lain, Trueman dan Titman (1998, dikutip dalam Meiryani \& Susanto 2019) menyatakan bahwa tingkat pengungkapan yang semakin mendekati penuh (full disclosure) akan mengurangi asimetri informasi atas kondisi yang dibutuhkan (necessary condition) untuk pengelolaan manajemen.

Pada praktiknya, BAZNAS Kota Magelang dalam pengambilan keputusan terkait penyaluran dana ZIS hanya berpatokan pada saldo tercatat. BAZNAS Kota Magelang menyimpulkan saldo tercatat dalam buku penerimaan dana ZIS adalah saldo yang siap untuk didistribusikan kepada mustahik di wilayah Kota Magelang sesuai dengan program kerja yang ada. Bagi internal BAZNAS Kota Magelang, informasi tersebut dirasa sudah cukup. Hal tersebut dikarenakan BAZNAS Kota Magelang tidak mengurus hal-hal selain transaksi keluar masuk dana, seperti mencatat depresiasi aset nonkas dan biaya implisit lainnya karena aset yang dimiliki oleh BAZNAS Kota Magelang merupakan aset milik pemerintah kota, sehingga pengelolaan akuntansi aset tetap dilakukan oleh Pemerintah Kota Magelang. Terkait aset nonkas yang dibeli menggunakan dana operasional BAZNAS, pencatatan atas aset nonkas tersebut secara keseluruhan dibebankan langsung di bulan terjadinya pengeluaran kas untuk pembelian aset tersebut.

Meskipun informasi akuntansi yang belum sesuai dengan standar tersebut dianggap oleh pihak internal BAZNAS sudah cukup mengakomodasi proses pengambilan keputusan, tetapi penyajian dan pengungkapan yang tidak sesuai standar membuat informasi yang tersedia tidak dapat dibaca secara penuh oleh muzaki. Muzaki menjadi tidak dapat mengetahui arah kebijakan dan prioritas utama dari program yang telah disusun oleh BAZNAS karena realisasi program kerja tidak tersaji secara detail dalam laporan keuangan. Selain terkait dengan program kerja, penyajian dan pengungkapan yang memenuhi standar juga membuat muzaki dapat mengetahui penggunaan dana dan dampak nyata perubahan atas dana yang telah disalurkan baik terkait dengan dana amil maupun dana nonamil. Oleh karena itu, penyajian informasi akuntansi yang sesuai standar PSAK 109 menjadi sangat krusial mengingat fungsi akuntansi zakat adalah sebagai media komunikasi antara amil dan pengguna laporan keuangan.

Menurut narasumber dari akademisi, selain terkait dengan fungsi pertanggungjawaban dan nilai amanah amil, belum diterapkannya PSAK 109 membuat BAZNAS Kota Magelang tidak memenuhi standar audit syariah untuk BAZNAS dan LAZ yang dilakukan oleh Kementerian Agama. Dengan tidak dapat dilakukannya proses audit di BAZNAS Kota Magelang, realisasi pengelolaan dana ZIS menjadi semakin tidak dapat dibaca secara terbuka oleh pihak eksternal.

\section{Faktor-Faktor yang Memengaruhi Penerapan PSAK 109}

Penerapan standar akuntansi PSAK 109 bagi lembaga amil pengelola zakat dan infak/sedekah dapat dilakukan ketika muncul keinginan dan komitmen yang kuat untuk mematuhinya. Kedua hal tersebut akan mendorong sebuah lembaga untuk menyusun dan melakukan berbagai cara serta strategi demi mencapai keberhasilan program sesuai dengan standar yang telah ditetapkan. Namun, selain keinginan dan komitmen yang kuat, skala prioritas serta kestabilan kondisi internal instansi dan dukungan eksternal dari pemerintah dan warga (muzaki) juga sangat memengaruhi kemajuan sebuah lembaga pelayanan masyarakat dalam menerapkan standar PSAK 109 yang ditetapkan.

Tujuan utama PSAK 109 disusun dan diterbitkan oleh Ikatan Akuntan Indonesia (IAI) adalah sebagai standarisasi dan penyamaan persepsi terkait akuntansi zakat di Indonesia untuk 


\section{JURNALKU}

Volume 1 No. 4, Desember 2021

memperoleh pelaporan keuangan yang lebih kredibel, amanah dan mencerminkan kondisi sesungguhnya dari suatu kegiatan pengelolaan dana ZIS. Pembuatan standar yang ada tentu sudah dipertimbangkan oleh dewan pembuat kebijakan IAI agar mudah dipahami dan dapat menyesuaikan dengan perubahan zaman. Riset yang dilakukan dengan sungguh-sungguh sebelum sebuah standar dibuat merupakan bentuk pertanggungjawaban dewan IAI atas kebijakan yang akan ditetapkan.

BAZNAS sebagai badan amil zakat resmi yang dibentuk pemerintah sudah seharusnya menggunakan dan mematuhi standar tersebut. Namun demikian, sampai dengan akhir tahun 2020, proses akuntansi yang dilaksanakan BAZNAS Kota Magelang, khususnya terkait dengan penyajian, pelaporan, dan pengungkapan dana ZIS masih belum sepenuhnya sesuai dengan PSAK 109. Padahal, penerapan standar PSAK 109 dalam laporan keuangan zakat dapat mendukung BAZNAS Kota Magelang untuk mewujudkan visi amanah, transparan dan profesional. Penerapan dan kepatuhan BAZNAS Kota Magelang terhadap PSAK 109 menjadi sangat krusial mengingat penyusunan laporan keuangan merupakan bentuk pertanggungjawaban atas dana ZIS yang berasal dari muzaki. Berdasarkan informasi Ketua Unit Pelaksana BAZNAS Kota Magelang, sampai dengan tahun 2019 sistem tradisional yang dijalankan BAZNAS Kota Magelang berjalan dengan baik dan sama sekali tidak menghambat kegiatan operasional BAZNAS Kota Magelang. Selanjutnya, pada awal 2020 Kementerian Agama Republik Indonesia melalui BAZNAS pusat menerbitkan surat edaran berupa imbauan yang bersifat segera kepada seluruh BAZNAS daerah yang belum menerapkan standar dalam proses akuntansi pengelolaan ZIS sesuai dengan PSAK 109 untuk dapat segera menerapkan standar tersebut. Setelah menerima surat edaran tersebut, BAZNAS Kota Magelang mulai berbenah dan mencari informasi terkait PSAK 109.

Terkait dengan faktor-faktor yang memengaruhi penerapan PSAK 109 pada BAZNAS Kota Magelang, setidaknya terdapat empat faktor yang menjadi alasan mengapa BAZNAS Kota Magelang belum sepenuhnya menerapkan PSAK 109. Keempat faktor tersebut adalah perbedaan persepsi terhadap urgensi penerapan PSAK 109, keterbatasan sistem teknologi informasi, keterbatasan sumber daya manusia, dan keterbatasan dukungan pemerintah daerah.

\section{Perbedaan Persepsi Terhadap Urgensi Penerapan PSAK 109}

Berdasarkan hasil wawancara dengan Staf Akuntansi dan Kepala Unit Akuntansi BAZNAS Kota Magelang terkait dengan urgensi penerapan PSAK 109, terdapat dua pandangan atau persepsi yang berbeda. Staf akuntansi mengatakan bahwa penerapan PSAK 109 beserta aplikasi yang mendukung akan sangat mempermudah proses pembukuan guna menghasilkan informasi keuangan yang lebih valid dan bersifat full disclosure. Staf akuntansi juga mengatakan bahwa dengan laporan keuangan yang baik, maka semua sistem di BAZNAS Kota Magelang, baik itu berkaitan dengan pengambilan keputusan maupun administrasi, dapat dikendalikan dengan mudah. Sementara itu, ketua unit pelaksana mengatakan bahwa kebijakan yang saat ini diterapkan dinilai sudah cukup dalam mengakomodasi keperluan pengambilan keputusan tanpa menimbulkan masalah yang berarti. Hal ini menunjukkan bahwa selain karena masalah administrasi dan juga imbauan dari BAZNAS pusat, penerapan PSAK 109 dipandang belum menjadi prioritas kegiatan yang harus segera dilakukan.

Adanya perbedaan persepsi terkait urgensi penerapan PSAK 109 di atas mengindikasikan bahwa pihak internal BAZNAS Kota Magelang belum memiliki suara yang bulat sehingga belum penerapan PSAK 109 secara memadai belum sepenuhnya dapat diwujudkan. Hal tersebut tentu menghambat proses standarisasi perlakuan akuntansi di BAZNAS Kota Magelang.

\section{Keterbatasan Sistem Teknologi Informasi}

Berdasarkan hasil wawancara dengan staf akuntansi BAZNAS Kota Magelang, kendala utama dalam pencatatan dana ZIS adalah keterbatasan sistem teknologi informasi. Lebih lanjut 


\section{JURNALKU}

Volume 1 No. 4, Desember 2021

dijelaskan bahwa pada saat lembaga amil memutuskan untuk menerapkan PSAK 109, maka pihak amil harus menyiapkan perangkat dan aplikasi yang mendukung proses pencatatan dan pembukuan yang sesuai dengan ketentuan PSAK 109. Karena pihak amil belum memiliki sistem teknologi yang mendukung hal tersebut, maka penerapan PSAK 109 pada BAZNAS Kota Magelang belum sepenuhnya dapat direalisasikan hingga akhir tahun 2020.

Keterbatasan sitem teknologi informasi menjadi masalah yang sangat mengganggu karena staf akuntansi harus melakukan input data, pemrosesan output data, dan input informasi secara manual menggunakan piranti lunak Microsoft Excel. Hal ini berbeda jika pembuatan laporan keuangan dapat dilakukan secara otomatis, yaitu dengan sekali input data pemasukan maupun pengeluaran sesuai dengan pos akun yang telah ditentukan, data-data yang ada akan terkoneksi dengan sistem aplikasi yang ada sehingga bisa langsung menghasilkan laporan keuangan sesuai format yang telah diprogram sebelumnya. Dengan kondisi yang terbatas tersebut, proses pengolahan data menjadi tidak efektif dan efisien.

\section{Keterbatasan Sumber Daya Manusia}

Selain keterbatasan fasilitas informasi teknologi, keterbatasan sumber daya manusia (pegawai) menjadi masalah yang tidak dapat dipisahkan dari siklus akuntansi. Dalam struktur organisasi BAZNAS Kota Magelang, dapat dilihat bahwa jabatan sekretaris dan ketua unit pelaksana dijabat oleh satu orang yang sama. Hal tersebut menunjukkan secara jelas bahwa dalam kepengurusan resmi harian, terjadi rangkap jabatan dikarenakan keterbatasan pegawai BAZNAS Kota Magelang. Sebenarnya BAZNAS Kota Magelang telah mencoba mengatasi masalah ini dengan mengadakan open recruitment relawan BAZNAS, tetapi sangat sulit untuk mendapatkan pegawai yang berkomitmen dan mampu bekerja dalam kondisi yang penuh dengan keterbatasan.

Keterbatasan sumber daya manusia pada BAZNAS Kota Magelang juga dapat dilihat dari alokasi beban kerja pegawai. Berdasarkan observasi lapangan dan hasil wawancara dengan staf akuntansi, beban kerja yang ditanggung staf akuntansi sangat besar. Dalam praktik di lapangan, staf akuntansi dituntut untuk ikut serta dalam pelaksanaan program pengumpulan dan penyaluran ZIS. Selain itu, staf akuntansi juga merangkap sebagai pengantar surat, petugas riset mustahik, dan mengurus administrasi surat. Kondisi tersebut menyebabkan staf akuntansi kurang fokus dengan tugas utamanya di bidang pencatatan akuntansi dan penyusunan laporan keuangan.

Selain keterbatasan dari sisi jumlah sumber daya manusia, kendala lain yang dihadapi BAZNAS Kota Magelang adalah keterbatasan kompetensi pegawai di bidang akuntansi zakat, khususnya terkait pemahaman PSAK 109. Menurut keterangan ketua unit pelaksana BAZNAS Kota Magelang, di antara kendala yang dihadapi adalah terdapat kesulitan dalam memahami standar pencatatan keuangan berdasarkan PSAK 109 sehingga hingga saat ini penerapan PSAK 109 belum dapat terealisasi. Hal ini diperkuat dengan penjelasan staf akuntansi yang menyatakan bahwa pihaknya belum pernah mendapatkan sosialiasi atau pemahaman mengenai PSAK 109. Dari keterangan tersebut, dapat diartikan bahwa selama ini staf akuntansi belum pernah mempelajari standar yang terdapat dalam PSAK 109. Staf akuntansi mengatakan bahwa pemahaman yang didapatkan sejauh ini hanya sebatas pengetahuan tentang keberadaan PSAK 109.

Terkait kesulitan pemahaman atas PSAK 109, berdasarkan hasil wawancara dengan seorang ahli ekonomi syariah yang juga berprofesi sebagai auditor, kesulitan dalam pemahaman PSAK 109 merupakan masalah persepsi karena transaksi dalam akuntansi pengelolaan dana ZIS sangat sederhana, yaitu hanya melibatkan pemasukan dan pengeluaran dana. Dengan demikian, staf yang pernah belajar akuntansi dipastikan bisa melakukan pencatatan sesuai standar asalkan memiliki fasilitas yang memadai. Hal tersebut sejalan dengan informasi 


\section{JURNALKU}

Volume 1 No. 4, Desember 2021

pertama yang diberikan oleh staf keuangan BAZNAS Kota Magelang yang mengatakan hambatan utama dalam penerapan adalah keterbatasan fasilitas teknologi informasi.

\section{Keterbatasan Dukungan Pemerintah Daerah}

Dukungan pemerintah merupakan kunci utama keberhasilan dalam upaya implementasi PSAK 109 pada BAZNAS Kota Magelang. Sebenarnya, langkah luar biasa telah dilakukan oleh Pemerintah Kota Magelang dengan menerbitkan surat edaran terkait imbauan dan kebijakan payment roll untuk pembayaran zakat mal atas penghasilan bagi ASN di bawah naungan Pemerintah Kota Magelang untuk secara otomatis terhubung dengan BAZNAS Kota Magelang. Hal tersebut tentu membawa dampak yang signifikan terhadap penerimaan dana ZIS hingga naik sebesar $300 \%$ pada kuartal pertama tahun 2021. Namun, selain kebijakan terkait pengumpulan dana ZIS, diperlukan dukungan terkait penerapan PSAK 109 pada BAZNAS Kota Magelang, baik dukungan kebijakan maupun dukungan dana guna mendukung keberlangsungan operasional BAZNAS Kota Magelang sehingga mampu mewujudkan visi BAZNAS Kota Magelang untuk menjadi badan amil zakat yang amanah, transparan, dan profesional.

Dukungan dana dari pemerintah daerah merupakan faktor yang sangat penting mengingat bahwa faktor-faktor yang telah terlebih dahulu dibahas dalam penelitian ini sangat berkaitan erat dengan masalah keuangan. Dengan kecukupan dana, permasalahan terkait keterbatasan sistem informasi teknologi dan keterbatasan jumlah dan kompetensi sumber daya manusia menjadi sangat mungkin untuk dapat diselesaikan. Selain itu, dengan adanya dana yang memadai, pengadaan peralatan teknologi informasi dapat dilakukan sehingga menghasilkan dampak positif terhadap operasional BAZNAS Kota Magelang. Dalam hal ini, dengan sistem teknologi informasi yang memadai, maka proses operasional secara manual yang membutuhkan banyak pegawai dapat dilakukan dengan lebih efektif dengan aplikasi yang terintegrasi. Selain itu, dengan tersedianya aplikasi dan berbagai software pendukung, maka penerapan PSAK 109 menjadi mungkin dilakukan karena sudah tersedianya alat yang dibutuhkan.

Selain berkaitan dengan pengadaan bidang teknologi informasi, ketersediaan dana dapat mendukung BAZNAS Kota Magelang untuk mempekerjakan akuntan yang ahli dalam bidang akuntansi dana ZIS sehingga dapat mengatasi permasalahan terkait minimnya pemahaman dan kompetensi pengelola zakat. Alternatif kedua yang dapat dilakukan adalah dengan adanya dana yang cukup adalah mengundang seorang ahli untuk mengisi pelatihan akuntansi zakat dan infak/sedekah berdasarkan PSAK 109 bagi para pegawai dan pengurus BAZNAS Kota Magelang.

\section{PENUTUP \\ Simpulan}

Berdasarkan hasil analisis yang telah dilakukan terhadap implementasi PSAK 109 pada BAZNAS Kota Magelang dan faktor yang memengaruhinya, dapat ditarik kesimpulan bahwa praktik pengelolaan dana zakat dan infak/sedekah pada BAZNAS Kota Magelang masih dilakukan secara tradisional dan belum sepenuhnya sesuai dengan PSAK 109, khususnya terkait pengukuran, penyajian, pelaporan, dan pengungkapan dana ZIS. BAZNAS Kota Magelang belum memiliki gambaran terkait perlakuan pengukuran atas penerimaan dana ZIS. Selain itu, sampai dengan akhir tahun 2020, BAZNAS Kota Magelang belum menyusun laporan keuangan amil. Dalam hal ini, amil hanya membuat laporan sederhana yang berisi penerimaan zakat dan infak/sedekah serta pengeluaran yang dilakukan. Selain itu, sampai dengan akhir tahun 2020, BAZNAS Kota Magelang juga belum melakukan pengungkapan atas dana nonhalal dan kinerja amil dan akun lainnya sesuai dengan PSAK 109. 


\section{JURNALKU}

Volume 1 No. 4, Desember 2021

Terkait faktor-faktor yang memengaruhi penerapan PSAK 109 pada BAZNAS Kota Magelang, terdapat empat faktor yang dapat diidentifikasi, yaitu perbedaan persepsi terhadap urgensi PSAK 109, keterbatasan sistem teknologi informasi, keterbatasan sumber daya manusia, dan keterbatasan dukungan dari pemerintah daerah. Keempat faktor tersebut menyebabkan BAZNAS Kota Magelang belum dapat menerapkan PSAK 109 dalam pengelolaan dana ZIS secara memadai. Dari keempat faktor tersebut, keterbatasan dukungan pemerintah daerah, khususnya dukungan dana, merupakan faktor penyebab utama mengapa PSAK 109 belum sepenuhnya diterapkan pada BAZNAS Kota Magelang. Dalam hal ini, dukungan dana dari pemerintah daerah merupakan faktor yang sangat penting mengingat faktor-faktor lainnya sangat berkaitan erat dengan masalah keuangan.

\section{Saran}

Agar penerapan PSAK 109 pada BAZNAS daerah dapat dilakukan secara optimal, pemerintah daerah perlu memberikan dukungan secara memadai, baik dukungan kebijakan maupun dukungan dana, yang dapat mengakomodasi kebutuhan sistem teknologi informasi dan kompetensi sumber daya manusia. Selain itu, penelitian ini mengindikasikan bahwa BAZNAS pusat dan Ikatan Akuntan Indonesia (IAI) perlu meningkatkan sosialisasi dan asistensi kepada BAZNAS daerah terkait penerapan PSAK 109. Terkait keterbatasan penelitian, penelitian ini hanya mengambil satu subjek penelitian dan hanya fokus pada penerapan PSAK 109 beserta faktor-faktor yang memengaruhinya. Untuk penelitian ke depan, diharapkan dapat menambah subjek penelitian dan menambah ruang lingkup penelitian, misalnya terkait penerapan Sistem Manajemen Informasi BAZNAS (SiMBA) pada lembaga amil zakat.

\section{DAFTAR PUSTAKA}

Arief, S. W. H., Manossoh, H., \& Alexander, S. W. (2017). Analisis Penerapan PSAK 109 Tentang Akuntansi Zakat pada Baznas Manado. Jurnal Riset Akuntansi Going Concern, 12(1), 98-107.

Aspers, P., \& Corte, U. (2019). What is Qualitative in Qualitative Research. Qualitative Sociology, 42(2), 139-160. https://doi.org/10.1007/s11133-019-9413-7

Badan Amil Zakat Nasional. (n.d). Profil. Diakses tanggal 20 Maret 2021, dari https://baznas.go.id/profil

Badan Amil Zakat Nasional (28 Mei 2020). Zakat dan Penanganan Covid-19. http://baznas.go.id/pendistribusian/kolom/direktur-pp/2511-zakat-dan-penanganan-covid19

Bakri. (2019). Penerapan Akuntansi Zakat dan Infak/Sedekah pada Badan Amil Zakat Nasional (BAZNAS) Kota Gorontalo. Jurnal Al-Buhuts, 15(2).

Bulutoding, L.-, \& Anggeriani, W.-. (2018). Akuntansi Zakat: Kajian PSAK 109 (Studi Kasus pada BAZNAS Kota Makassar). Akuntabilitas: Jurnal Ilmiah Ilmu-Ilmu Ekonomi, 11(1), 23-37. https://doi.org/10.35457/akuntabilitas.v11i1.446

Dompet Dhuafa. (n.d.). Sejarah Pengelolaan Zakat Pada Masa Khalifah Umar bin Khattab. Diakses 28 Desember 2020 dari https://www.dompetdhuafa.org/id/berita/detail/khalifahumar-bin-khattab

Hadijah, S. (2019). Analisis Penerapan PSAK 109 Tentang Akuntansi Zakat, Infaq, dan Sedekah pada Badan Amil Zakat Nasional Kabupaten Majene. Journal of Economic, Public, and Accounting (JEPA), 1(2), 58-67. https://doi.org/10.31605/jepa.v1i2.297

Hadziq, M. F. (2013). Fikih Zakat, Infaq, dan Sedekah. Ekonomi Ziswaf.

Ikbal, M., Mulyani, H., Medinal. (2021). Analisis Penerapan Akuntansi Zakat dan BAZNAS Kota Pangkalpinang. 8(2), 1-11.

Kartini, T. (2019). Analisis Penerapan Psak 109 Tentang Pencatatan Akuntansi Zakat, Infaq/Sedekah (ZIS) pada BAZNAS Kabupaten Sukabumi. ISSN 2502-3632 (Online) 
ISSN 2356-0304 (Paper) Jurnal Online Internasional \& Nasional Vol. 7 No.1, Januari Juni 2019 Universitas 17 Agustus 1945 Jakarta, 53(9), 1689-1699. www.journal.uta45jakarta.ac.id

Kieso, D. E., Weygandt, J. J., \& Warfield, T. D. (2014). Intermediate Accounting: IFRS Edition, 2nd Edition. https://books.google.co.id/books?id=_KOqBAAAQBAJ

Latief, N. F. (2019). Managing Zakat in the 4.0 Era: An Implementation of Simba in BAZNAS of North Sulawesi. Share: Jurnal Ekonomi dan Keuangan Islam, 8(2), 238-255. https://doi.org/10.22373/share.v8i2.5550

Majid J, Asse A, Fatimah, Fajrin F. (2020). PSAK 109: Upaya Mewujudkan Good Zakat Governance BAZNAS Provinsi Sulawesi Selatan. Laa Maisyir, 1(Fakultas Ekonomi dan Bisnis Islam UIN Alauddin Makassar), 16.

Masamah, M. (2019). Tinjauan Undang-Undang Nomor 23 Tahun 2011 Tentang Zakat Terhadap Peran Pemberdayaan Zakat Secara Produktif oleh Penyuluh Agama Islam. Istidal: Jurnal Studi Hukum 23. https://ejournal.unisnu.ac.id/JSHI/article/view/1371

Nisa, A. C., Indarwati, H., Muthi'ah, S., \& Anwar, S. (2021). Laporan Keuangan BAZNAS di Era Digital 4.0 : Tinjauan atas PSAK 109. Wahana Islamika: Jurnal Studi Keislaman, 7(1), 114-135.

Ohoirenan, M. H., \& Fithria, A. (2020). Analisis Penerapan PSAK 109 Pada Badan Amil Zakat Nasional Kota Tual. AKTSAR: Jurnal Akuntansi Syariah, 3(2), 135. https://doi.org/10.21043/aktsar.v3i2.8123

Putri, J. I. F., \& Awalina, P. (2021). Analisis Penerapan PSAK No. 109 Tentang Zakat, Infaq Dan Shadaqah Pada Badan Amil Zakat Nasional (BAZNAS) Kabupaten Nganjuk. JCA (Jurnal Cendekia Akuntansi), 2(1), 49-61.

Rahman, T. (2015). Akuntansi Zakat, Infak dan Sedekah (PSAK 109): Upaya Peningkatan Transparansi dan Akuntabilitas Organisasi Pengelola Zakat (OPZ). Muqtasid: Jurnal Ekonomi dan Perbankan Syariah, 6(1), 141. https://doi.org/10.18326/muqtasid.v6i1.141164

Rahmawati, I. D., \& P, F. A. (2013). Penerapan Akuntansi Zakat (PSAK No.109) pada Lembaga Amil Zakat (LAZ) Lembaga Manajemen Infaq (LMI) Cabang Sidoarjo dan Badan Amil Zakat Nasional (BAZNAS) Kabupaten Sidoarjo. Prosiding, 109, 92-104.

Redaksi DDTCNews. (27 Februari 2020). Potensi Zakat Rp217 Triliun, BAZNAS Hanya Kantongi Rp9 triliun. DDTC News. https:// news.ddtc.co.id/potensi-zakat-rp217-triliunbaznas-hanya-kantongi-rp9-triliun-19209

Ridjali, I.S., Malik. E., (2021). Penerapan Akuntansi PSAK 109 Tentang Akuntansi Zakat, Infak/Sedekah pada Badan Amil Zakat Nasional Kota Baubau. 3(1). 1-15.

Ritonga, P. (2017). Analisis Akuntansi Zakat Berdasarkan PSAK No. 109 pada Badan Amil Zakat Nasional (BAZNAS) Sumatera Utara. Jurnal Khitabah. 1(1).

Rizal, Fitri, S. A., \& Minazzulami, H. (2017). PSAK 109: A Study Of Its Application At BAZNAS Solok Regency. Jurnal IMARA, 1(1), 1-16. https://ojs.iainbatusangkar.ac.id/ojs/index.php/jurei/article/viewFile/992/869

Rokib. A., Wisnandani. I., Murhasanah. E. (2021). Analisis Penerapan PSAK 109 dalam Menyusun Laporan Keuangan di BAZNAS Kabupaten Tasikmalaya. 1(2), 99-110.

Sari, J. M., Titisari. K. H., Nurlaela. S., (2020). Application of PSAK 109 in Organization of Zakat Managers (Opz) In Sragen District (BAZNAS, LAZISNU, LAZISMU, and LAZKU). 4(3), 390-400.

Sartika D., Eliza. N., Ilyas. A. (2021) Penerapan PSAK No. 109 Tentang Akuntansi Zakat, Infak/Sedekah pada Badan Amil Zakat Nasional Menggunakan Aplikasi SiMBA di BAZNAS Kota Padang. Jurnal Ekonomi \& Bisnis Dharma Andalas. Ekonomi dan Bisnis, 


\section{JURNALKU}

Volume 1 No. 4, Desember 2021

19(1), 113-126.

Sayidah, N. (2019). Penerapan Akuntansi Zakat dan Infak / Sedekah pada Badan Amil Zakat Nasional (BAZNAS) Kabupaten Bojonegoro. Jurnal Analisa Akuntansi Dan Perpajakan, 2(2), 183-199. https://doi.org/10.25139/jaap.v2i2.1395

Shanaz, S. (2015). Application of Accounting Zakat, Infaq/Sedekah Based on PSAK 109 at Badan Amil Zakat the Province North Sulawesi. Jurnal Riset Ekonomi, Manajemen, Bisnis, dan Akuntansi, 3(4), 315-324.

Susanto, A., \& Meiryani. (2019). Full Disclosure in Financial Reporting. International Journal of Scientific and Technology Research, 8(6), 340-345.

Susilowati, L., \& Khofifa, F. (2020). Kesesuaian Akuntansi Zakat, Infak dan Sedekah dengan PSAK 109 BAZNAS Kabupaten Tulungagung. JAS (Jurnal Akuntansi Syariah), 4(2), 162-180. https://doi.org/10.46367/jas.v4i2.246

Wijayanti, C., Roziq, A., \& Irmadariyani, R. (2020). Penerimaan Pengguna Terhadap Sistem Informasi Manajemen BAZNAS dan Kesesuaian dengan PSAK Nomor 109 (Studi Kasus pada Badan Amil Zakat Nasional Kabupaten Jember). E-Journal Ekonomi Bisnis dan Akuntansi, 7(1), 42. https://doi.org/10.19184/ejeba.v7i1.15553

Yanuar, F., Amriya, Y., \& Priyono, N. (2020). Review Laporan Keuangan Baznas Kabupaten Magelang dengan PSAK 109. Jurnal Akuntansi Dan Pajak, 21(01). https://doi.org/10.29040/jap.v21i1.1161 